\title{
FIRST RECORD OF PIGNOSED ARROWTOOTH EEL, DYSOMMA BREVIROSTRE (ACTINOPTERYGII: ANGUILLIFORMES: SYNAPHOBRANCHIDAE), FROM THE AEGEAN SEA
}

\author{
İlker AYDIN, S. Can AKÇINAR*, and Ozan SOYKAN \\ Faculty of Fisheries, Ege University, Bornova, Izmir, Turkey
}

Aydin İ., Akçinar S.C., Soykan O. 2009. First record of pignosed arrowtooth eel, Dysomma brevirostre (Actinopterygii: Anguilliformes: Synaphobranchidae), from the Aegean Sea. Acta Ichthyol. Piscat. 39 (1): $51-53$.

\begin{abstract}
In 2008, a specimen of a pignosed arrowtooth eel, Dysomma brevirostre (Facciolà, 1887), was caught by a bottom trawling operation at Sigacik Bay (Aegean Sea), Turkey. Total length (TL) and weight of the fish were $23.2 \mathrm{~cm}$ and $2.00 \mathrm{~g}$, respectively. This study reports the first record of D. brevirostre from the Aegean Sea and logs a new species for the Turkish Ichthyofauna.
\end{abstract}

Keywords: Synaphobranchidae, pignosed arrowtooth eel, Dysomma brevirostre, Eastern Mediterranean, Aegean Sea, Turkey, first record

Synaphobranchids (Synaphobranchidae) are benthic eels consisting of 10 genera and 32 species (Nelson 2006). The pignosed arrowtooth eel, Dysomma brevirostre (Facciolà, 1887), is distinguished from the other members of the family by its bulbous snout, heavily ornamented with papillae, and lack of pectoral fins. It has been recorded from the North Eastern Atlantic, along the south coast of Portugal (Marques and Saldanha 1998) and the Madeira Islands (Blache et al. 1970); in Miami waters in the Western Atlantic (Böhlke and Robins 1968), and in Hawaiian waters in the Central Pacific (Smith and Castle 1981). Moreover, the larvae of D. brevirostre have been found in the Eastern South Atlantic off the coast of Cabinda, Congo and Gabon (Blache et al. 1970).

The species was observed several times along the Mediterranean (Fig. 1). However, a small number of specimens have been obtained from the previous studies. The occasional findings have been associated with the ability of this species to evade the sampling gear (e.g., trawl nets and dredges) because of its body shape and size, as well as, its possible low population density (Sion et al. 2008). Sion et al. (2008) suggested that the species would probably spread throughout the basin due to its wide distribution (in tropical and subtropical areas) and its pelagic larval dispersion (Sion et al. 2008).

The objective of this study is to report the first record of $D$. brevirostre for the Aegean Sea and for Turkish marine ichthyofauna.

In April 2008, one specimen of D. brevirostre was collected during bottom trawling at 220-300 m depth range,

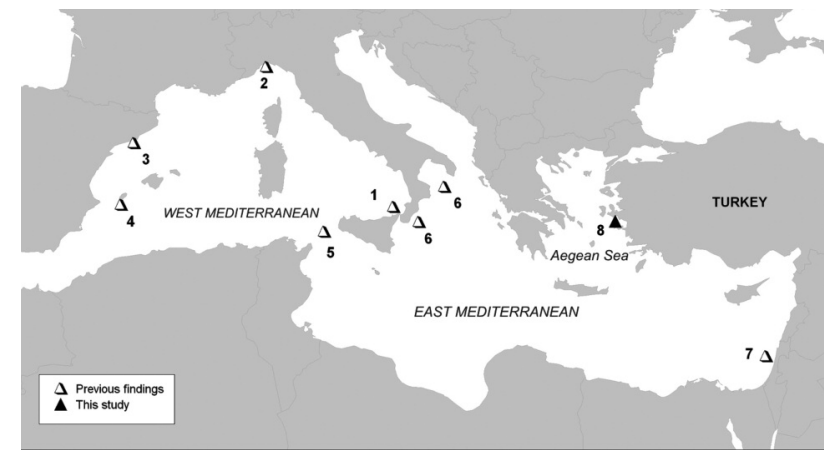

Fig. 1. Distribution of previous findings of D. brevirostre in the Mediterranean and the new record in the Aegean Sea: 1 Facciolà (1887); 2 Trotti (1948); 3 Stefanescu et al. (1990); 4 Morales-Nin et al. (2003); 5 Ragonese et al. (2001); 6 Sion et al. (2008); 7 Golani (1996); 8 This study

off Sigacik Bay (southern Aegean Sea, Turkey, Fig. 2). The trawling operation started at lat $38^{\circ} 2^{\prime} 06^{\prime \prime} \mathrm{N}$, long $26^{\circ} 41^{\prime} 17^{\prime \prime} \mathrm{E}$ and ended at lat $37^{\circ} 56^{\prime} 29^{\prime \prime} \mathrm{N}$, long $26^{\circ} 48^{\prime} 49^{\prime \prime}$ E. The fish was fixed in $4 \%$ formalin and preserved at the Mugla University Faculty of Fisheries Museum (MUSUM-PIS-463). The measurements were carried out to the nearest $0.1 \mathrm{~mm}$ by a calliper and meristic counts were made using a stereomicroscope. The taxonomic key of Smith (2002) was used to identify the specimen.

The specimen collected has a total length and weight of $23.2 \mathrm{~cm}$ and $2.00 \mathrm{~g}$, respectively.

\footnotetext{
* Correspondence: Dr S. Can Akçinar, Ege Üniversitesi, Su Ürünleri Fakültesi, Bornova-Izmir, Turkey 35100 , phone: +90 (232) 3434000 ext. 5347, e-mail: can.akcinar@ege.edu.tr or cakcinar@gmail.com
} 


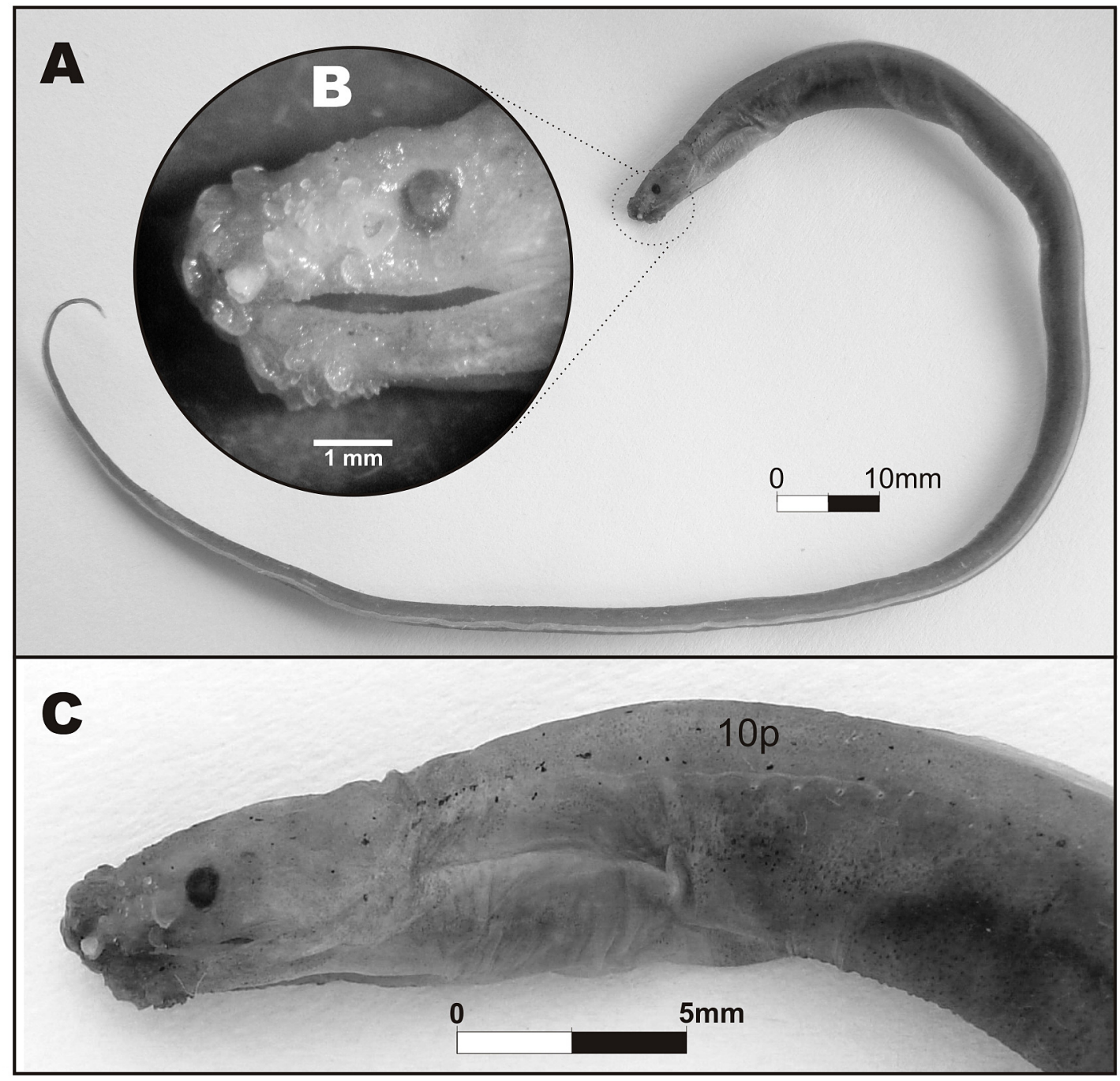

Fig. 2. D. brevirostre caught in Sigacik Bay, Aegean Sea; A the entire specimen; B papillose snout with distinctive anterior and posterior nostrils; $\mathbf{C}$ lateral line pores $(10 \mathrm{p})$

Morphometric measurements and parameters of Dysomma brevirostre

Table 1

\begin{tabular}{lrccc}
\hline \multirow{2}{*}{ Character } & \multicolumn{4}{c}{ Value } \\
\cline { 2 - 5 } & in mm & in \%SL & in \%PAL & in \%HL \\
\hline Total length (TL) & 232 & - & - & - \\
Head length (HL) & 15.9 & 6.9 & 36.6 & - \\
Head width & 2.8 & 1.2 & 6.5 & 17.6 \\
Head height & 3.9 & 1.7 & 9.0 & 24.5 \\
Max eye diameter & 0.7 & 0.3 & 1.6 & 4.4 \\
Inter-orbital width & 1.9 & 0.8 & 4.4 & 11.9 \\
Pre-orbital length & 3.4 & 1.5 & 7.8 & 21.4 \\
Post-orbital length & 12.5 & 5.4 & 28.8 & 78.6 \\
Upper jaw length & 4.9 & 2.1 & 11.3 & 30.8 \\
Lower jaw length & 4.4 & 1.9 & 10.1 & 27.7 \\
Jaw length & 5.5 & 2.4 & 12.7 & 34.6 \\
Pre-dorsal length & 21.9 & 9.5 & 50.5 & - \\
Pre-anal length (PAL) & 43.4 & 18.8 & - & - \\
Gill opening length & 1.1 & 0.5 & 2.5 & 6.9 \\
\hline
\end{tabular}

$\mathrm{TL}=$ total length; $\mathrm{PAL}=$ pre-anal length; $\mathrm{HL}=$ head length. 
Its brown body was covered with a various tiny black spots. Confluent dorsal, caudal and anal fins were pale coloured. Its papillose snout had conspicuous nasal openings (Fig. 2B). The main morphometric measurements and their percentages of the total length (TL), pre-anal length (PAL), and head length (HL) are given in Table 1. There were pores on the lateral line. The main morphological measurements and their relationships are consistent with the previous findings by various authors (Supino 1905, Grassi 1913, Böhlke and Robins 1968, Blache et al. 1970, Smith and Castle 1981, Saldanha and Bauchot 1986, Sion et al. 2008).

Although recent findings of the species are mostly confined to the Western Mediterranean and Western Ionian Sea, there is another record from Israeli coast of the Eastern Mediterranean (Golani 1996). The scarcity of observations could be due to the sampling method or its low population density. The easternmost record (Golani 1996) and the specimen caught in the Aegean Sea (Fig. 1) support the opinions of Sion et al. (2008) concerning the spreading of the species throughout the basin. However; it could also indicate that the species has already spread along the Mediterranean basin (Fig. 1).

\section{REFERENCES}

Blache J., Maul G.E., Saldanha L. 1970. Présence d'adultes et de larves de Nettodarus brevirostre et de Nettodarus sp. dans l'Atlantique oriental (Pisces, Anguilliformi, Nettodaridae). Arquivos do Museu Bocage 2 (16): 319-331.

Böhlke J.E., Robins C.R. 1968. Biological investigations of the deep sea. XXXVI. The eel Nettodarus brevirostris in the western Atlantic. Marine Science Bulletin 18 (2): 477-480.

Facciolà L. 1887. Intorno a due Lepadogastrini ed un nuovo Nettastoma del Mare di Sicilia. Lettera al Dottore Cristoforo Bellotti di Milano. Il Naturalista Siciliano 6: 163-167. [In Italian.]

Golani D. 1996. The marine ichthyofauna of the eastern Levant-History, inventory, and characterization. Israel Journal of Zoology 42: 15-55.

Grassi B. 1913. Metamorfosi dei Murenoidi; Ricerche sistematiche ed ecologiche. Iena Fisher. [In Italian.]

Marques A., Saldanha L. 1998. Three new records of bathyal fish species from the Portuguese slope: Notes on their morphology and distribution. Cybium 22: 285-289.
Morales-Nin B., Sardà F., Maynou F., Cartes J.E., Moranta J., Massutí E., Company J.B., Rotllant G., Bozzano A., Stefanescu C. 2003. Size influences and zonation patterns in fishes and crustaceans from the deep water communities of the Western Mediterranean. Journal of NAFO 31: 401-413.

Nelson J. S. 2006. Fishes of the world. 4th edn. John Wiley and Sons, New York NY.

Ragonese S., Zagra M., Di Stefano L., Bianchini M.L. 2001. Effect of codend mesh size on the performance of the deepwater bottom trawl used in the red shrimp fishery in the Strait of Sicily (Mediterranean Sea). Hydrobiologia 449: 279-291. DOI: 10.1023/A:1017564530716.

Saldanha L., Bauchot M.L. 1986. Family: Synaphobranchidae. Pp. 586-592. In: Whitehead P.J.P., Bauchot M.-L., Hureau J.-C., Nielsen J., Tortonese E. (eds.) Fishes of the north-eastern Atlantic and the Mediterranean. Vol. 2. UNESCO, Paris.

Sion L., Battista D., Mastrototaro F., Carlucci R. 2008. New findings of pignosed arrowtooth eel Dysomma brevirostre (Synaphobranchidae) in the Western Ionian Sea (Mediterranean Sea). Cybium 32 (2): 189-190.

Smith D.G. 2002. Synaphobranchidae. Cutthroat eels. Pp. 719-723. In: Carpenter K.E. (ed.) FAO species identification guide for fishery purposes. The living marine resources of the Western Central Atlantic. Vol. 2: Bony fishes. Part 1 (Acipenseridae to Grammatidae).

Smith D.G., Castle P.H.J. 1981. New Hawaiian records for two dysommine eels (Pisces, Synaphobranchidae). Bulletin of Marine Science 31 (2): 460-461.

Stefanescu C., Lloris D., Rucabado J. 1990. Primeras citas de Cataetyx laticeps (Osteichthyes, Bythitidae) y Dysomma brevirostre (Osteichthyes, Synaphobranchidae) en el Mar Catalan (Mediterraneo Iberico). Miscellania Zoologica 14: 135-143.

Supino F. 1905. Il Todarus brevirostris Gr. e Cal. Ricerche fatte nel Laboratorio d'Anatomia Normale della R. Università di Roma ed in altri laboratori biologici 2 (3): 255-259.

Trotti L. 1948. Un nuovo esemplare ittiologico della fauna profonda del Golfo Ligure: Todarus brevirostris (Facciolà, 1887). Atti della Accademia Ligure di Scienze e Lettere 4: 93-102.

Received: 24 November 2008

Accepted: 26 January 2009

Published electronically: 20 May 2009 